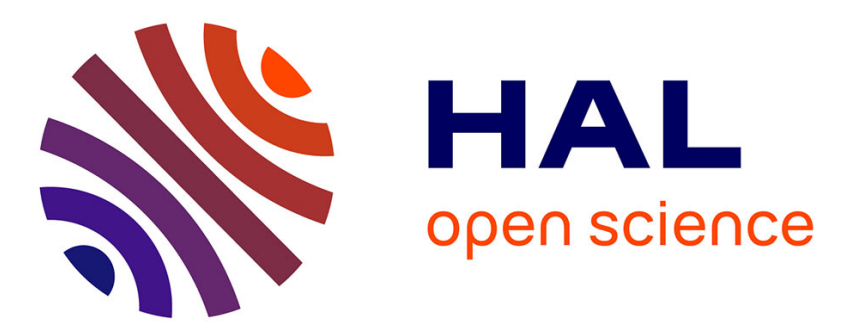

\title{
A novel apparatus for accurate measurements of solid solubilities in supercritical phases
}

Martial Sauceau, Jacques Fages, Jean-jacques Letourneau, Dominique Richon

\section{To cite this version:}

Martial Sauceau, Jacques Fages, Jean-jacques Letourneau, Dominique Richon. A novel apparatus for accurate measurements of solid solubilities in supercritical phases. Industrial and engineering chemistry research, 2000, 39 (12), pp.4609-4614. 10.1021/ie000181d . hal-01668428

\section{HAL Id: hal-01668428 \\ https://hal.science/hal-01668428}

Submitted on 15 Mar 2018

HAL is a multi-disciplinary open access archive for the deposit and dissemination of scientific research documents, whether they are published or not. The documents may come from teaching and research institutions in France or abroad, or from public or private research centers.
L'archive ouverte pluridisciplinaire HAL, est destinée au dépôt et à la diffusion de documents scientifiques de niveau recherche, publiés ou non, émanant des établissements d'enseignement et de recherche français ou étrangers, des laboratoires publics ou privés. 


\title{
A Novel Apparatus for Accurate Measurements of Solid Solubilities in Supercritical Phases
}

\author{
M. Sauceau, ${ }^{*} \dagger$ J. Fages ${ }^{\dagger}$ J.-J. Letourneau ${ }^{\dagger}$ and D. Richon ${ }^{\star}$ \\ Ecole des Mines d'Albi-Carmaux, F81013 Albi, France, and Ecole des Mines de Paris, \\ F77305 Fontainebleau, France
}

\begin{abstract}
A new apparatus for the measurement of solid solubilities in supercritical fluids is described in detail. It is based on an analytical open-flow method: the composition of the phase is obtained by analyses, and the solvent flows continuously through the solid solute. Solubilities of naphthalene in supercritical $\mathrm{CO}_{2}$ in the pressure range of 8-30 $\mathrm{MPa}$ are reported for the isotherms 308.15 and $318.15 \mathrm{~K}$. The solubility data are then correlated using three densitybased models.
\end{abstract}

\section{Introduction}

Supercritical fluids (SCFs) are widely used in a broad field of applications. Particle generation is generally handled with the RESS (rapid expansion of a supercritical solution) and SAS (supercritical antisolvent) processes, which are of particular interest. To develop these techniques, knowledge of the solubility of the solid compounds in the corresponding medium is the basic initial information required. Solubility is a good measurement of the interaction between species. The accurate determination of the influence of pressure and temperature on the solubility level provides in sight into the influence of these variables on extraction behavior.

Several experimental techniques have been developed for investigating high-pressure equilibria ${ }^{1}$. Two types of methods can be used, depending on the way the composition is measured: synthetic methods and analytical methods. Synthetic methods involve the indirect determination of equilibrium composition without sampling. ${ }^{2,3}$ They require the preparation of systems of given total composition according to each point in the $(T, x)$ or $(P, x)$ diagrams and are thus time-consuming. In analytical methods, the compositions of the phases in equilibrium are obtained by analyses after sampling. These methods are the most widely used for determining solid-fluid equilibrium. Two types of analytical methods can be distinguished according to the way equilibrium is obtained: closed-circuit methods and open-circuit methods. In the closed-circuit method subgroup, there are the pure static methods, in which the system is allowed to attain an equilibrium state in appropriately stirred conditions, ${ }^{4,5}$ and the phaserecirculation static methods, in which at least one phase circulates, providing the agitation necessary to achieve thermodynamic equilibrium. In the open-circu it method group, either one of the phases ${ }^{6}$ or the whole mixture ${ }^{7}$ is circulated. In both cases, it is essential that the residence time of the flowing phase, in experimental conditions, is longer than the time needed to reach the equilibrium.

* Author to whom correspondence should be addressed. E-mail: martial.sauceau@enstimac.fr. Fax: 33 (0)5 634930 25 .

$\dagger$ Ecole des Mines d'Albi-Carmaux.

\# Ecole des Mines de Paris.
Table 1. Source and Purity of Chemicals

\begin{tabular}{lll}
\hline \multicolumn{1}{c}{ compound } & \multicolumn{1}{c}{ source } & purity \\
\hline carbon dioxide & Air Liquide S.A. & $99.995 \%$ \\
naphthalene & Aldrich & $98 \%$ \\
hexane & Sds & $99 \%$
\end{tabular}

A novel apparatus has been developed to measure solubilities in pure and mixed solvents. It is based on an open-circuit analytical method. The equilibrium cell was designed to achieve stirring and efficient mass transfer in order to reach thermodynamic equilibrium. A back-pressure regulator (BPR) maintains a constant pressure throughout the line. At the outlet, where the supercritical fluid is expanded, a liquid solvent stream is used to collect the solute. The apparatus is designed to avoid solid precipitation and potential clogging, problems encountered with most of the open-circuit techniques used to measure solubilities in supercritical fluids. The solubility of the solid in the supercritical fluid is calculated from the measured data.

\section{Experimental Section}

1. Materials. The sources and purities of the various compounds used are given in Table 1 . These materials were used without any further purification, except for careful degassing of naphthalene.

2. Equipment and Procedures. The flow diagram of the apparatus is shown in Figure 1. The main parts of this apparatus are two high-pressure pumps, a mixer, a heater, a heat exchanger, an equilibrium cell, a backpressure regulator, and a separator.

Liquid carbon dioxide is compressed at ambient temperature by means of a syringe pump P1 (Isco, model 260D) to the desired pressure. The Isco pump can be operated in either constant-flow or constant-pressure mode for flow rates ranging from $0.1 \mu \mathrm{L} \min ^{-1}$ to 90 $\mathrm{mL} \mathrm{min}^{-1}$ and pressures up to $50 \mathrm{MPa}$. The potential cosolvent is introduced by means of another syringe pump P2, in a parallel flow, at a flow rate depending on the desired composition. To achieve homogeneous mixing of the two liquid solvents, they are circulated through a mixer, $M$. The mixer is a special device built specifically for this setup. The high-pressure fluid then passes through a heater, $\mathrm{H}$, which is made of a brass body, containing a heating resistance, around which is coiled the solvent circuit (stainless steel tubing). The 


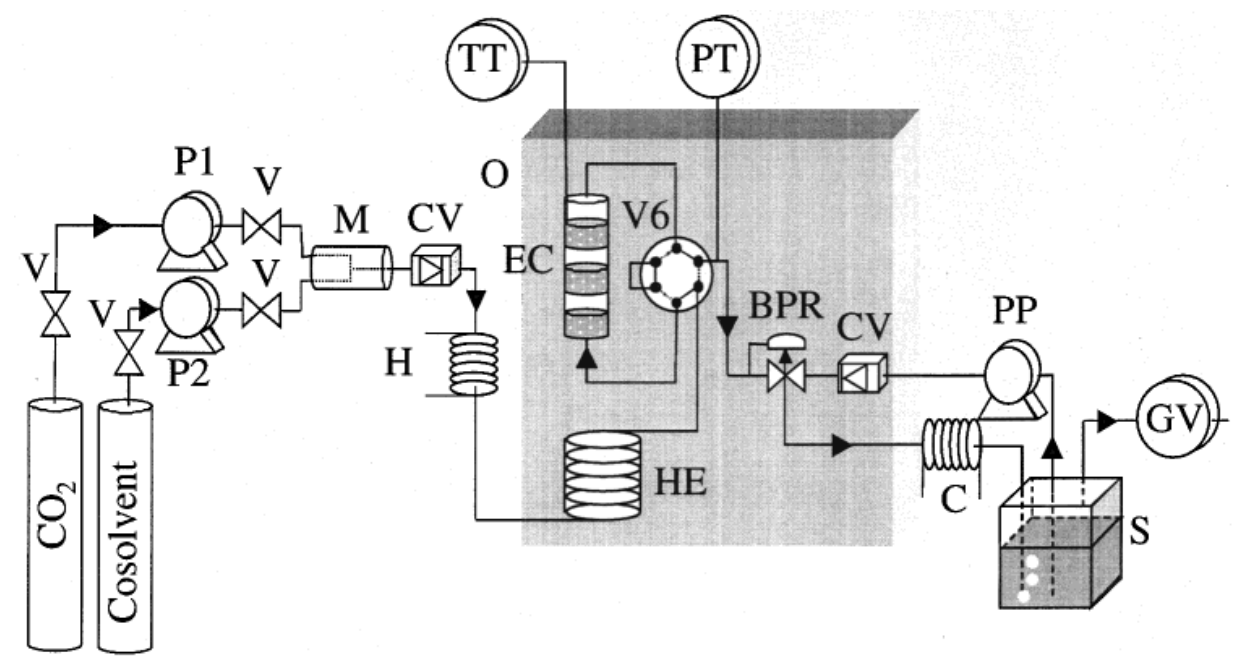

$\mathrm{V}: 2$ way valves; $\mathrm{P} 1, \mathrm{P} 2$ : high pressure pumps; $\mathrm{M}:$ mixer; $\mathrm{CV}:$ checking valve; $\mathrm{H}:$ heater;

$\mathrm{O}$ : thermostated oven; $\mathrm{HE}$ : heat exchanger; V6 : 6 way-2 position valve; $\mathrm{EC}$ : equilibrium cell;

TT : temperature transducer; PT : pressure transducer; BPR : back pressure regulator;

C : cooler; S : separator; PP : peristaltic pump; GV : gas volumeter;

Figure 1. Flow diagram of the apparatus.

heater, $\mathrm{H}$, is used to rapidly heat the solvent to temperatures above its critical temperature. The supercritical fluid then enters an oven (Spame), where the solubility cell is thermoregulated. The oven can be used for temperatures up to $400 \mathrm{~K}$, with temperature regulation within $0.1 \mathrm{~K}$. Because of the thermal inertia of the equilibrium cell, its internal temperature is found to be stable to within $0.05 \mathrm{~K}$. A heat exchanger, HE, contained in the oven, is used to set the temperature of the solvent at the desired level (temperature of the required solubility measurement) before it enters the solubility cell. HE consists of a brass cylinder around which is wound the stainless steel solvent circuit. The cylinder and tubing are covered with a brass radiator. Downstream of the heat exchanger, a six-way, two-position high-pressure Valco valve is located in the circuit to either direct the supercritical fluid to the cell or bypass it. This provides a means for removing eventual solid deposits from the line. Cylindrical in shape, the cell EC contain s three compartments placed one above the other and fitted at their bottoms with stainless steel sintered disks and $\mathrm{O}$ rings. This is equivalent to three different cells connected in series. The solid powder, for which solubility measurements are required, is placed inside the three compartments, which have a total volume of about $5 \mathrm{~cm}^{3}$. The sintered disks prevent stripping of the solid during the experiment and allow a small pressure drop, advantageous for attaining saturation, while a good dispersion of the supercritical solvent is achieved. EC withstands pressures up to $50 \mathrm{MPa}$ at temperatures up to $400 \mathrm{~K}$. The cell cap is sealed in the bottom part using a silicone $\mathrm{O}$ ring. The two parts (cap and bottom) are pressed against each other with a fast-connecting mechanical device. The pressure of the supercritical phase is monitored upstream and released downstream through the BPR (Tescom, model 26-1722), which can be either heated or not so that it can be at temperatures higher or lower than the extraction temperature. After homemade modifications, the BPR allows control of the inline pressures to within $0.5 \%$. It can be used up to
$473 \mathrm{~K}$ and $70 \mathrm{MPa}$. At the outlet of the BPR, the pressure is reduced to about atmospheric pressure, and then a recovering liquid solvent (a sufficiently good solvent at atmospheric pressure to recover all of the solute) stream is used to get the solute in liquid state for collection. Without this solvent, the solute would precipitate during the pressure drop, and this would lead to potential clogging. Finally, a separator $\mathrm{S}$ is used to vent the gas and collect the solvent phase. At the end of each experimental run, the liquid solvent line is washed with fresh solvent to recover all of the solute. The total volume of gaseous $\mathrm{CO}_{2}$ (extraction solvent), $V_{1}$, is measured by means of a volumeter $\mathrm{GV}$, and the concentration of solid in the solute recovering liquid phase $C_{2}^{\mathrm{L}}$ is measured by gas or liquid chromatography. With these two data and the total volume of the solute recovering liquid solvent, $V_{\mathrm{L}}$, determined, the solubility, $y_{2}$, of the solid in supercritical fluid is calculated by

$$
y_{2}=\frac{n_{2}}{\sum n_{i}}
$$

where

$$
n_{i}=\frac{V_{1} \rho_{1}}{1000 M_{1}}
$$

and

$$
n_{2}=\frac{C_{2}^{\mathrm{L}} V_{\mathrm{L}}}{1000 M_{2}}
$$

$n$ is the mole number, $\rho$ the density, and $M$ the molecular weight. The solubility uncertainty depends strongly on the experiment duration: the longer the time, the more accurate the quantities used in the calculation of the solubility. As a consequence, the 
Table 2. Solubility Data for Naphthalene in Supercritical $\mathrm{CO}_{2}(T=308.15 \mathrm{~K}$ and $T=318.15 \mathrm{~K})$

\begin{tabular}{|c|c|c|c|}
\hline \multicolumn{2}{|c|}{$T=308.15 \mathrm{~K}$} & \multicolumn{2}{|c|}{$T=318.15 \mathrm{~K}$} \\
\hline$P(\mathrm{MPa})$ & $y_{2}$ & $P(\mathrm{MPa})$ & $y_{2}$ \\
\hline 8.05 & 0.0044 & 8.49 & 0.0011 \\
\hline 13.43 & 0.0138 & 9.83 & 0.0060 \\
\hline 13.52 & 0.0139 & 14.65 & 0.0206 \\
\hline 14.85 & 0.0146 & 15.06 & 0.0208 \\
\hline 15.05 & 0.0147 & 15.30 & 0.0215 \\
\hline 20.03 & 0.0161 & 19.77 & 0.0237 \\
\hline 20.08 & 0.0163 & 24.98 & 0.0258 \\
\hline 24.82 & 0.0169 & 29.70 & 0.0278 \\
\hline 29.76 & 0.0174 & & \\
\hline 29.92 & 0.0175 & & \\
\hline
\end{tabular}

experiment duration should be optimized for good accuracy in the result, without an excessively long experiment.

Temperatures of the heater, the pressure transducer, and the BPR are monitored to better than $0.1 \mathrm{~K}$ by a temperature regulator (West Mini, model 6100) fitted with a J-type thermocouple. The temperature in the cell is measured directly in its body through a 4 -wire $100-\Omega$ platinum probe, to within $0.02 \mathrm{~K}$ as a result of a careful calibration, performed against a $25-\Omega$ reference platinum probe. The pressure is measured in the out-stream line of the cell. The pressure transducer (Druck, model PTX611) can measure pressures up to $35 \mathrm{MPa}$ at temperatures up to $400 \mathrm{~K}$ with an accuracy of $4 \times 10^{-3}$ $\mathrm{MPa}$ as a result of a calibration performed using a dead weight balance (Desgranges et Hu ot, model 5202S CP). It is thermostated (at a fixed temperature above the solubility measurement temperatures) by a small oven made of a brass jacket containing a heating resistance (with an internal thermocouple) connected to a thermoregulator (West Mini, model 6100). There are two main reasons for the thermal regulation of the pressure transducer: (a) to avoid condensation or solid deposit and (b) because the response coefficient of the pressure transducer is slightly dependent on temperature.

3. Testing of the Equipment. An important requirement in the design of the apparatus was to obtain a saturated stream flowing outside the cell. To confirm the efficiency of the equipment over a large range of operating conditions, measurements have been performed at various flow rates. When there is no sensitive effect on the measured solubility values in a given range of flow rates, the equilibrium is confirmed in this range. This applicability range is valid for the studied compound but does not necessarily apply to a nother. Separate experiments are therefore required to confirm operating flow rates for each solute of interest.

The validity of the technique was determined by measuring naphthalene solubility in supercritical $\mathrm{CO}_{2}$. Corresponding data are available in the literature and provide a good basis for quantifying tests.

Hexane was used as the recovering liquid solvent. A $\mathrm{CO}_{2}$ flow time of $20 \mathrm{~min}$ at $0.75 \mathrm{~mL} \mathrm{~min}^{-1}$ was sufficient to obtain a reproducibility better than 3\%. Sample analysis was performed with a Hewlett-Packard gas chromatograph (model 5890) fitted with an HP automatic injector (model 7675) and an SGE capillary column (model 50QC3/BP10 0.5). Analyses on fresh hexane used for additional cleanings of the recovering solvent line were performed after each experiment to verify that no naphthalene residue had been left in the line. The solubility data are listed in Table 2 for two temperatures. Figures 2 and 3 show comparisons of our

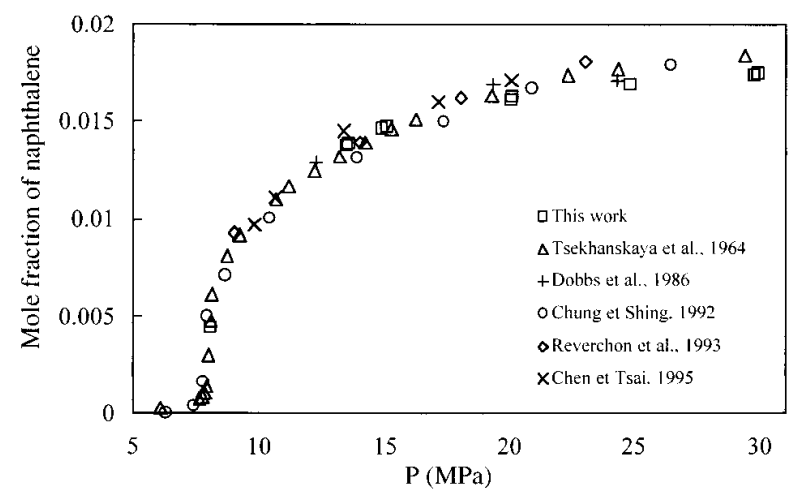

Figure 2. Comparison of our solubility data results with previous works at $T=308.2 \mathrm{~K}$.

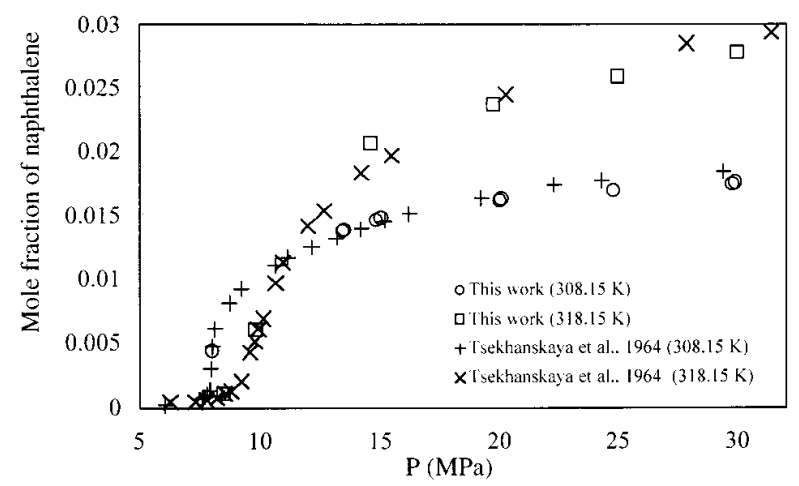

Figure 3. Comparison of our solubility data results with the Tsekhanskaya et al. ${ }^{8}$ data .

data with those reported in the literature. ${ }^{8-12}$ Our solubility measurements are in excellent agreement with those from previous works.

This apparatus provides accurate measurements of solid solubilities with a short experiment time because of the circulation of the supercritical fluid. To enhance the accuracy and to measure very low solubility, the experiment time can be increased. For screening purposes and rough solubility measurements, only very short measurement times are necessary. This apparatus can also be used for extraction studies.

\section{Modeling}

For modeling solid solubilities in supercritical fluids, different equations of state can be used, such as the Peng-Robin son ${ }^{13}$ cubic equation of state (PR EoS). For this option however, physicochemical properties of the solute and the solvent must be known (critical parameters, acentric factors, molar volumes, vapor pressures, etc.). Such data are available, from the literature, for $\mathrm{CO}_{2}$ and for most of the classical cosolvents, but this is not true for complex solids related to the pharmaceutical industry. At first, the solute critical parameters can be estimated using a group contribution method. ${ }^{14,15}$ If results are not satisfactory, critical parameters can be treated as adjustable parameters of the thermodynamic model. ${ }^{16,17}$

Modeling the solubility of solids using density instead of pressure as the independent variable is very useful, because it does not require the mentioned physical properties. There exist several empirical den sity-based correlations. In the present work, solubilities are correlated by three methods. In the first method, the mole fraction of naphthalene, $y_{2}$, is related to the reduced 
density of carbon dioxide, $\rho_{\mathrm{r} 1},{ }^{18}$ by

$$
\ln y_{2}=c+d \rho_{\mathrm{r} 1}
$$

where $\rho_{\mathrm{r} 1}$ is equal to $\rho_{1} / \rho_{\mathrm{c} 1}$ and $c$ and $d$ are adjusted on the basis of the experimental data.

The second method used in this work was suggested by Schmitt and Reid ${ }^{19}$ as follows:

$$
\ln E=e+f \rho_{1}
$$

with

$$
E=\frac{P y_{2}}{P_{2}^{\mathrm{sat}}}
$$

where $E$ is the enhancement factor, $P_{2}^{\text {sat }}$ the saturation vapor pressure of the solute, and $\rho_{1}$ the density of the fluid. The coefficients $e$ and $f$ are adjusted on the basis of the experimental data. The $P_{2}^{\text {sat }}$ of naphthalene is obtained by means of an interpolation of experimental data, ${ }^{20} \mathrm{u}$ sing the following expression:

$$
\ln P_{2}^{\text {sat }}=\alpha-\frac{\beta}{T}
$$

The calculated $P_{2}^{\text {sat }}$ values are $35 \mathrm{~Pa}$ at $308.15 \mathrm{~K}$ and $126 \mathrm{~Pa}$ at $318.15 \mathrm{~K}$.

The third method for correlating the solubility data used the model proposed by Chrastil. ${ }^{21}$ This model can be regarded as a macroscopic description of the surroundings of the molecules in the fluid phase. It is based on the hypothesis that one molecule of a solute A associates with $k$ molecules of a gas $\mathrm{B}$ to form one molecule of a solvato complex $\mathrm{AB}_{k}$ in equilibrium with the system. The definition of the equilibrium constant through thermodynamic considerations leads to the following expression for the solubility:

$$
\ln \left(C_{2}\right)=k \ln \left(\rho_{1}\right)+\frac{a}{T}+b
$$

where $C_{2}$ is the concentration of the solute in the supercritical phase, $k$ is the association number, $a$ is dependent on the heat of solvation and heat of vaporization of the solute, and $b$ is dependent on the molecular weights of the species. $k, a$, and $b$ are adjusted on the basis of experimental solubility data. In most cases, solvato complexes are not stoichiometric, and it is not expected that $k$ will be an integer.$^{21}$ The concentration $C_{2}$ is calculated by

$$
C_{2}=\rho_{1} \frac{M_{2} y_{2}}{M_{1}\left(1-y_{2}\right)+M_{2} y_{2}}
$$

These three developments suggest linear relationships between $\ln y_{2}$ and $\rho_{\mathrm{r} 1}$ for eq $4, \ln E$ and $\rho_{1}$ for eq 5 , and $\ln \left(C_{2}\right)$ and $\ln \left(\rho_{1}\right)$ for eq 8 , with slopes equal to $d$, $f$, and $k$, respectively. We have chosen to use the density of the pure fluid because, for most of the solids, the solubility is low and the variation of the saturated supercritical phase density because of the solute is negligible. For naphthalene, which shows a high solubility, the difference is always less than $1 \%$. The density $\rho_{1}$ and the concentration $C_{2}$ under the operating conditions points are listed in Table 3 .
Table 3. Density and Concentration under Experimental Conditions

\begin{tabular}{rcccccc}
\hline \multicolumn{3}{c}{$T=308.15 \mathrm{~K}$} & & \multicolumn{3}{c}{$T=318.15 \mathrm{~K}$} \\
\cline { 1 - 2 } \cline { 5 - 6 } $\begin{array}{c}P \\
(\mathrm{MPa})\end{array}$ & $\begin{array}{c}\rho_{1} \\
\left(\mathrm{~kg} \mathrm{~m}^{-3}\right)^{a}\end{array}$ & $\begin{array}{c}C_{2} \\
\left(\mathrm{~kg} \mathrm{~m}^{-3}\right)\end{array}$ & & $\begin{array}{c}P \\
(\mathrm{MPa})\end{array}$ & $\begin{array}{c}\rho_{1} \\
\left(\mathrm{~kg} \mathrm{~m}^{-3}\right)^{a}\end{array}$ & $\begin{array}{c}C_{2} \\
\left(\mathrm{~kg} \mathrm{~m}^{-3}\right)\end{array}$ \\
\hline 8.05 & 380 & 4.8 & & 9.83 & 426 & 8.2 \\
13.43 & 764 & 29.9 & & 14.65 & 696 & 40.2 \\
13.52 & 766 & 30.2 & & 15.06 & 707 & 41.2 \\
14.85 & 793 & 32.8 & & 15.30 & 714 & 42.9 \\
15.05 & 797 & 33.2 & & 19.77 & 799 & 52.8 \\
20.03 & 870 & 39.6 & & 24.98 & 864 & 61.9 \\
20.08 & 871 & 40.1 & & 29.70 & 909 & 68.9 \\
24.82 & 919 & 43.8 & & & \\
29.76 & 959 & 47.0 & & & \\
29.92 & 960 & 47.3 & & &
\end{tabular}

${ }^{a}$ The density of the $\mathrm{CO}_{2}$ is calculated by using the PR EoS. ${ }^{13}$

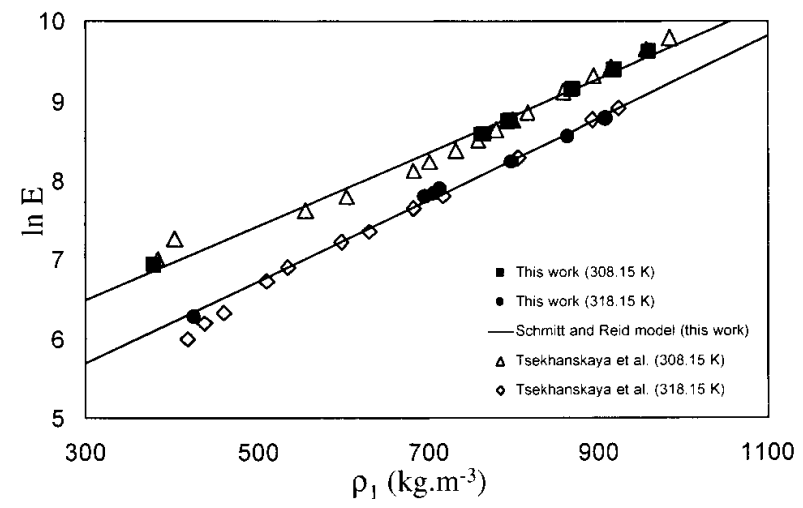

Figure 4. Enhancement factor vs density. Correlation proposed by Schmitt and Reid. ${ }^{19}$

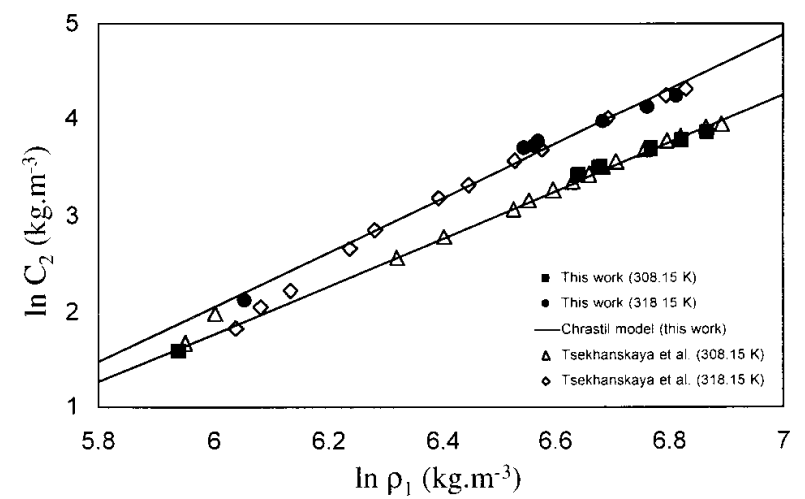

Figure 5. Concentration of naphthalene vs density. Correlation proposed by Chrastil. ${ }^{21}$

The results for the three correlations are presented in Table 4. We have limited the range of pressures to our investigated range because correlations were not found to be strictly linear for all data sources. Our experimental results were satisfactorily regressed using the three linear functions, although eq 4 gives a higher average absolute deviation (AAD). The results for eqs 5 and 8 are illustrated in Figures 4 and 5, respectively.

The correlation of the Tsekhanskaya et al. ${ }^{8}$ data gives good results too. In the case of eqs 4 and 5 , the coefficients are close to our values. If we use the coefficients obtained for eq 5, the AAD of our data remains on the same order as those obtained for the direct regression (the bottom two lines in Table 4). This demonstrates the consistency between the two sets of data.

For the Chrastil model, the $k$ values obtained with the Tsekhankaya et al. ${ }^{8}$ data show a small temperature 
Table 4. Correlation of Solubility Data with Three Equations

\begin{tabular}{|c|c|c|c|c|c|c|c|c|c|c|c|c|}
\hline \multirow[b]{2}{*}{$\operatorname{data}^{a}$} & \multirow[b]{2}{*}{$T(\mathrm{~K})$} & \multirow[b]{2}{*}{$\mathrm{pts}$} & \multicolumn{3}{|c|}{ eq 4} & \multicolumn{3}{|c|}{ eq 5} & \multicolumn{4}{|c|}{ eq 8} \\
\hline & & & $c$ & $d$ & $\operatorname{AAD}(\%)^{b}$ & $e$ & $10^{3} f$ & $\operatorname{AAD}(\%)^{b}$ & $k$ & $a / 10^{3}$ & $b$ & $\overline{\mathrm{AAD}(\%)^{c}}$ \\
\hline 1 & 308.15 & 10 & -6.20 & 1.11 & 8.67 & 5.00 & 4.65 & 4.34 & 2.49 & -6.78 & 8.84 & 4.06 \\
\hline 1 & 318.15 & 7 & -6.06 & 1.36 & 13.02 & 4.15 & 5.16 & 4.95 & 2.84 & -3.54 & -3.86 & 8.33 \\
\hline 1 & overall & 17 & & & & 4.39 & 5.26 & 26.73 & 2.61 & -4.78 & 1.53 & 6.41 \\
\hline 2 & 308.15 & 16 & -6.04 & 1.04 & 4.63 & 5.15 & 4.58 & 10.18 & 2.40 & -6.11 & 7.28 & 3.01 \\
\hline 2 & 318.15 & 12 & -6.42 & 1.57 & 13.58 & 3.80 & 5.60 & 5.22 & 3.12 & -2.50 & -8.99 & 7.16 \\
\hline 2 & overall & 28 & & & & & & & 2.69 & -3.51 & -3.10 & 8.39 \\
\hline 1,2 & 308.15 & 26 & -6.08 & 1.05 & 6.56 & 5.13 & 4.61 & 7.92 & 2.42 & -1.69 & -7.24 & 3.30 \\
\hline 1,2 & 318.15 & 19 & -6.34 & 1.52 & 13.44 & 3.88 & 5.50 & 6.10 & 3.05 & -2.23 & -9.40 & 8.41 \\
\hline 1 & 308.15 & 10 & & & & 5.15 & 4.58 & 4.50 & & & & \\
\hline 1 & 318.15 & 7 & & & & 3.80 & 5.60 & 8.16 & & & & \\
\hline
\end{tabular}

dependence, from 2.4 at $308.15 \mathrm{~K}$ to 3.1 at $318.15 \mathrm{~K}$, which is confirmed by the AAD increase when all data are taken into account (fourth to sixth line in Table 4). On the contrary, the temperature dependence of our $k$ value is not significant: the AAD remains practically constant when all our data are gathered (top three lines in Table 4). This conclusion is in good agreement with the results of Chrastil, who obtained parallel lines in the plot of $\ln \left(C_{2}\right)$ vs $\ln \left(\rho_{1}\right)$. The correlation can thus be written

$$
\ln \left(C_{2}\right)=f(T, P)=k \ln \left[\rho_{1}^{\mathrm{EoS}}(T, P)\right]+\frac{a}{T}+b
$$

to provide a relation between $C_{2}, P$, and $T$ with, for a given gas and solute, constant values of $k, a$, and $b$. A value of 2.6 for the association constant $k$ seems to be suitable for correlating all of our experiments.

\section{Conclusion}

A new apparatus for very accurate measurements of solid solubilities in supercritical fluids has been designed, built, and tested. Measurements of the solubility of naphthalene in supercritical carbon dioxide were carried out at 308.15 and $318.15 \mathrm{~K}$ over a range of pressures typically encountered in supercritical processes. The comparison with previous works indicates the validity of this apparatus, based on an analytical open-circuit method. The data were correlated with three density-based models, in particular with the one proposed by Chrastil, which provides an estimation of the number of solvent molecules per molecule of solute engaged in the solvato complex.

\section{Nomenclature}

$a, b=$ coefficients for eq 8

$c, d=$ coefficients for eq 4

$e, f=$ coefficients for eq 5

$\mathrm{AAD}=$ average absolute deviation

$C=$ concentration $\left(\mathrm{kg} \mathrm{m}^{-3}\right)$

$E=$ enhancement factor

$k=$ association number $\left(\right.$ Chrastil ${ }^{21}$ model $)$

$M=$ molecular weight $\left(\mathrm{g} \cdot \mathrm{mol}^{-1}\right)$

$n=$ mole number $(\mathrm{mol})$

$P=$ pressure $(\mathrm{MPa})$

$T=$ temperature $(\mathrm{K})$

$V=$ volume $\left(\mathrm{m}^{3}\right)$

$y=$ mole fraction

Greek Symbols

$\rho=$ density $\left(\mathrm{kg} \mathrm{m}^{-3}\right)$

$\alpha, \beta=$ coefficients for eq 7

\section{Subscripts}

$\mathrm{c}=$ critical property

cal $=$ calculated

$\exp =$ experimental

$\mathrm{L}=$ recovering liquid solvent

$\mathrm{r}=$ reduced property

$1=$ light solvent component (carbon dioxide)

2 = heavy solute component (naphthalene)

\section{Superscripts}

EoS $=$ calculated by means of an equation of state $\mathrm{L}=$ recovering liquid solvent

sat $=$ saturation

\section{Literature Cited}

(1) Fornari, R.; Alessi, P.; Kikic, I. High-Pressure Fluid Phase Equilibria: Experimental Methods and Systems Investigated (1978-1987). Fluid Phase Equilib. 1990, 57, 1-33.

(2) Fontalba, F.; Richon, D.; Renon, H. Simultaneous Determination of Vapor-Liquid Equilibria and Saturated Densities Up to $45 \mathrm{MPa}$ and $433 \mathrm{~K}$. Rev. Sci. Instrum . 1984, 55(6), 944-951.

(3) Valtz, A.; Laugier, S.; Richon, D. Bubble Pressures and Saturated Liquid Molar Volumes of DifluoromonochloromethaneFluorochloroethane Binary Mixtures: Experimental Data and Modelling. Int. J. Refrig. 1986, 9, 282-289.

(4) Figuiere, P.; Hom, J . F.; Laugier, S.; Renon, H.; Richon, D.; Szwarc H. Vapor-Liquid Equilibria Up to $40000 \mathrm{Kpa}$ and 400 ${ }^{\circ} \mathrm{C}$ : A New Static Methodology. AIChE J. 1980, 26, 872-875.

(5) Laugier, S.; Richon, D. New Apparatus to Perform Fast Determinations of Mixture Vapor-Liquid Equilibria Up to $10 \mathrm{Mpa}$ and 423 K. Rev. Sci. Instrum. 1986, 57, 469-472.

(6) Richon, D.; Antoine, P.; Renon, H. Infinite Dilution Activity Coefficients of Linear and Branched Alkanes from $\mathrm{C}_{1}$ to $\mathrm{C}_{9}$ in $n$-Hexadecane by Inert Gas Stripping. Ind. Eng. Chem. Process Des. Dev. 1980, 19, 144-147.

(7) Legret, D.; Houzelle, C.; Richon, D.; Renon, H. VaporLiquid Equilibria of Corrosive Components by a Dynamic Method: a New Flow Apparatus. Fluid Phase Equilib. 1983, 11, 179.

(8) Tsekhanskaya, Y.; Iomtev, M.; Mushkina, E. Solubility of Naphthalene in Ethylene and Carbon Dioxide under Pressure. Russ. J. Phys. Chem.1964, 9, 1173-1176.

(9) Dobbs, J .; Wong, J .; Johnston, K. Nonpolar Cosolvents for Solubility Enhancement in Supercritical Fluid Carbon Dioxide. $J$. Chem. Eng. Data 1986, 31, 303-308.

(10) Chung, S. T.; Shing, K. S. Multiphase Behavior of Binary and Ternary Systems of Heavy Aromatic Hydrocarbons with Supercritical Carbon Dioxide. Part I. Experimentals Results. Fluid Phase Equilib. 1992, 81, 321-341.

(11) Reverchon, E.; Russo, P.; Stassi, A. Solubilities of Solid Octacosane and Triacontane in Supercritical Carbon Dioxide. $J$. Chem. Eng. Data 1993, 38, 458-460.

(12) Chen, J .-W.; Tsai, F.-N. Solubilities of Methoxybenzoic Acid Isomers in Supercritical Carbon Dioxide. Fluid Phase Equilib. 1995, 107, 189-200.

(13) Peng, D.-Y.; Robinson, D. A New Two-Constant Equation of State. Ind. Eng. Chem. Fundam . 1976, 15, 59-64. 
(14) Ting, S.; Macnaughton, S.; Tomasko, D.; Foster, N. Solubility of Naproxen in Supercritical Carbon with and without Cosolvents. Ind. Eng. Chem. Res. 1993, 32, 1471-1481.

(15) Crampon, C.; Charbit, G.; Neau, E. High-Pressure Apparatus for Phase Equilibria Studies: Solubility of Fatty Acid Esters in Supercritical $\mathrm{CO}_{2}$. J. Supercrit. Fluids 1999, 16, 1120 .

(16) Cross, W.; Akgerman, A.; Erkey, C. Determination of Metal-Chelate Complex Solubilities in Supercritical Carbon Dioxide. Ind. Eng. Chem. Res. 1996, 35, 1765-1770.

(17) Subra, P.; Castellani, S.; Ksibi, H.; Garrabos, Y. Contribution to the Determination of the Solubility of $\beta$-Carotene in Supercritical Carbon Dioxide and Nitrous Oxide: Experimental Data and Modeling. Fluid Phase Equilib. 1997, 131, 269-286.

(18) Giddings, J. C.; Myers, M. N.; King, J. W. Dense Gas Chromatography at Pressures to $2000 \mathrm{~atm}$. J. Chromatogr. Sci. 1969, 7, 276-283
(19) Schmitt, W. J .; Reid, R. C. The Influence of the Solvent Gas on Solubility and Selectivity in Supercritical Extraction. In Supercritical Fluid Technology; Penninger, J. M. L., Radosz, M. McHugh, M. A., Krukonis, V. J., Eds.; Elsevier: Amsterdam, 1985.

(20) Handbook of Chemistry and Physics; Lide R. D., Ed.; CRC Press: Boca Raton, FL, 1997-1998.

(21) Chrastil, J . Solubility of Solids and Liquids in Supercritical Gases. J. Phys. Chem. 1982, 86, 3016-3021. 